\title{
Dual citizenship and the perceived loyalty of immigrants
}

\author{
Jasinskaja-Lahti, Inga
}

2020-10-01

Jasinskaja-Lahti , I , Renvik (Mähönen), T A , van der Noll , J , Eskelinen , V , Rohmann , A

\& Verkuyten, M 2020 , ' Dual citizenship and the perceived loyalty of immigrants ', Group

processes \& intergroup Relations , vol. 23 , no. 7 , 1368430219872809 , pp. 996-1013 . https://doi.org/10.1177/1368

http://hdl.handle.net/10138/327007

https://doi.org/10.1177/1368430219872809

unspecified

acceptedVersion

Downloaded from Helda, University of Helsinki institutional repository.

This is an electronic reprint of the original article.

This reprint may differ from the original in pagination and typographic detail.

Please cite the original version. 
Running head: PERCEIVED CITIZENSHIP AND GROUP LOYALTY

The MS accepted for publication in Group Processes \& Intergroup Relations

\section{Dual Citizenship and Perceived Loyalty of Immigrants}

Inga Jasinskaja-Lahti*1, Tuuli Anna Renvik ${ }^{1}$, Jolanda Van der Noll ${ }^{2}$, Viivi Eskelinen ${ }^{1}$, Anette Rohmann $^{2}, \&$ Maykel Verkuyten ${ }^{3}$

${ }^{1}$ University of Helsinki, Finland

${ }^{2}$ FernUniversität in Hagen, Germany

${ }^{3}$ University of Utrecht, the Netherlands

* corresponding author: inga.jasinskaja@ helsinki.fi

Acknowledgements

The authors thank Petja Sjö for preliminary analyses conducted for the study, and Annu-Riina Lamberg for practical assistance during the project.

Funding

The study has been supported by the Kone Foundation Grant (4704917) to SOPU project of Prof. Inga Jasinskaja-Lahti.

Declaration of Conflicting Interests

The authors declare that there is no conflict of interest.

Word count:

Abstract 149

Main text 7998 (including figures, tables, footnotes and Appendix 1)

Footnotes 101

References 1221

Tables 946 (included in the main text word count)

Six tables, two figures and one appendix are included in the manuscript. 


\section{PERCEIVED CITIZENSHIP AND GROUP LOYALTY}

\section{Abstract}

This survey experiment examined national majority group members' reactions to immigrants' citizenship status with a focus on dual citizenship. A sample of 779 participants $\left(n_{\text {Finland }}=\right.$ $174 ; n_{\text {Netherlands }}=377 ; n_{\text {Germany }}=228$ ) was used to examine whether immigrants' citizenship status affects trust towards immigrants, willingness to accept immigrants in strategic positions, and support for immigrants' social influence in society. Perceived group loyalties were expected to mediate these relationships. Compared to national citizens, dual citizens were perceived as having lower national loyalty and higher foreign loyalty. Compared to foreign citizens, dual citizens were perceived to have higher national loyalty but equally high foreign loyalty. Higher national loyalty was further associated with higher trust, acceptance and support, whereas higher foreign loyalty was associated with lower trust, acceptance and support. These findings are discussed in relation to societal debates on dual citizenship and the limited social psychological research on this topic.

Key Words: three-nation study, citizenship status, dual citizenship, perceived loyalty, immigrants, survey experiment 
PERCEIVED CITIZENSHIP AND GROUP LOYALTY

\section{Dual Citizenship and Perceived Loyalty of Immigrants}

"Finnish citizens have obligations towards the Finnish state. If there are citizens with dual obligations, it makes you ponder" (Sauli Niinistö, the President of the Republic of Finland, 2-04-2017)

"I want that only people with only Dutch nationality are allowed to vote. And I also want that one can only vote for candidates with a single nationality. It is a matter of our existence. Too many people have been elected whom it at least looks that they have a double loyalty (Geert Wilders, leader of the Dutch populist party PVV, 7-04-2018).

"Dual citizenship needs to be closely scrutinized. It needs to be clear to which country the person's loyalty pertains.” (Thomas Kreuzer, CSU group chairman in the Bavarian parliament, 20-04-2017).

With increasing immigration, politicized questions of national citizenship and allegedly divided loyalties of immigrants have arisen all around Europe. This discussion has evolved especially around dual citizenship, which implies rights and obligations in relation to two countries. An increasing number of states permit dual citizenship, but as shown in the quotes above and in opinion polls conducted among national majority group members (Centraal Bureau voor de Statistiek, 2011; infratest dimap, 2017; Yle News, 2017), there are concerns about divided loyalties. For majority members, immigrants' dual citizenship might lead to suspicions of disloyalty, because immigrants can be perceived as deviant members who compromise national unity and coalition (Kunst, Thomsen, \& Dovidio, 2018a).

Although citizenship status has profound implications for individuals and societies and therefore is a major topic of study in political science, political philosophy, and legal studies, 


\section{PERCEIVED CITIZENSHIP AND GROUP LOYALTY}

to date there is very little social psychological research on citizenship (see Stevenson, Dixon, Hopkins, \& Luyt, 2015). Citizenship is an important, concrete marker of legal and political group membership: based on citizenship status, individuals have specific civil rights and obligations, can participate in politics, and are expected to have a sense of belonging and solidarity with others who share one's citizenship (Bloemraad, 2015).

With the present research, we aim to investigate whether dual citizenship of immigrants affects how their group loyalties are perceived by national majority group members, and whether these perceptions have ramifications for their trust in immigrants, willingness to accept immigrants in strategic societal positions, and willingness to support immigrants' social influence in society. We address these questions using an experimental design in which we compare majority members' attitudinal reactions to an immigrant person holding national (country of residence), foreign (country of origin) or dual (country of residence and country of origin) citizenship in three European countries: Finland, Germany, and the Netherlands. We focus on majority group members' reactions to immigrants with Russian (in Finland) and Turkish (in Germany and the Netherlands) background who can legally possess all three types of citizenship status in these countries. In the three countries, these respective immigrant-origin groups are the largest in size and represent established Diaspora groups. Moreover, international tensions of Russia and Turkey with Europe and European countries mean that the questions of loyalty and political allegiance are relevant for the public in Europe.

\section{Group Loyalty and Dual Citizenship}

Group loyalty implies moral responsibility and obligation to act in a way that supports the group's unity, functioning, and continuing existence (see e.g., Hildreth, Gino, \& Bazerman, 2016; Zdaniuk \& Levine, 2001). Thus, when immigrants are assumed to have a lack of national loyalty or a competing loyalty with their country of origin, it becomes 


\section{PERCEIVED CITIZENSHIP AND GROUP LOYALTY}

difficult to trust, accept and support them, especially in positions of influence and power (e.g., Faist et al., 2004; Kunst et al., 2018a; Wimmer \& Glick Schiller, 2002). Against this background, immigrants' dual citizenship creates an important and interesting avenue for social psychological research.

In social psychology, there is increasing interest in complex identity categories (for review, see Kang \& Bodenhausen, 2015). Especially, dual identities have been studied quite extensively from the viewpoints of self-understanding (e.g., sense of ethnic and national belonging; Settles \& Buchanan, 2014), ingroup representations (Dovidio, Gaertner, \& Saguy, 2008), and cross-categorization (Crisp \& Hewstone, 2006). Related to this line of research, studies by Levy and colleagues (for a review, see Love \& Levy, 2019) suggest that people with dual identities (e.g., Israeli Arabs) may be perceived as bridges between the two cultural groups they are associated with (e.g., Israelis and Palestinians), i.e., as gateway group members. These perceptions, in turn, may alleviate intergroup tensions between these groups. In a related study conducted in the U.S, it was found that White Americans evaluated immigrants with self-expressed dual or common (i.e., American) identity to be more White and less of a threat to society than immigrants with a separate foreign identity (Kunst, Dovidio, \& Dotsch, 2018b).

However, dual identities also provide a perceptual challenge and can activate multiple, potentially conflicting stereotypes and prejudices (Kang \& Bodenhausen, 2015). Especially in situations with uncertain or missing information, complex categorizations, or ambiguous cues, cognitions and behaviors often become biased (Brewer, 2000; Kang \& Bodenhausen, 2015). When such perceptual challenges occur in contexts characterized by intergroup conflict, a backlash effect of dual group membership could happen (Kunst et al., 2018a; Levy, Saguy, Halperin, \& van Zomeren, 2017a; Levy, Saguy, van Zomeren, \& Halperin, 2017b) due to majority group members' fear of mixed and shifting loyalties (Levy et al., 2017a, p. 2). In a series of five studies, Kunst and colleagues (2018a) showed that majority group members 


\section{PERCEIVED CITIZENSHIP AND GROUP LOYALTY}

perceived dual self-identifiers as less loyal to the majority group compared to common identifiers, especially if the other membership group of the target was perceived as a rival of one's ingroup. Perceptions of (dis)loyalty rather than perceived (dis)identification and perceived adherence to group norms were found to undergird bias toward minority-group members who explicitly defined themselves in terms of dual identity. Self-expressed duality raised loyalty concerns because of the risks for the unity and welfare of the nation. Loyalty concerns, in turn, were found to drive bias toward minority group members. In the current study, we aim to go beyond this research in three ways.

First, Kunst and colleagues (2018a) argued for replication research "with less explicit cues of the target's identities" (p. 27). Self-expressed (dual) identification communicates a sense of group belonging and commitment and so coincides with perceived identities and group loyalties. However, as pointed out by Kang and Bodenhausen (2015), when based on more subtle cues or identity markers, observers' perceptions of target's group membership result in simplistic conceptions of the target's identity as they are both shaped by and reinforcing cognitive biases. Thus, more subtle cues about target's identity might evoke stronger (negative) reactions than those found by Kunst and colleagues (2018). Moreover, citizenship rights and benefits, as such, do not necessarily reflect nor depend on selfidentification but rather refer to the legal status bestowed by the state, and immigrants can apply for (dual) citizenship for a variety of reasons other than identification (Harpaz \& Mateos, 2018; Pogonyi, 2018). At the same time, among immigrants, both national and dual citizenship are always a result of action undertaken by the holder of the citizenship, which means that they could also be identity building blocks of the target. Therefore, in this study, we approach immigrants' citizenship status as a marker of political group membership that may entail aspects of both their objective and subjective group belonging.

Second, in their research on perceived (dis)loyalty, Kunst and colleagues (2018a) manipulated common national and dual self-identification but did not consider foreign 


\section{PERCEIVED CITIZENSHIP AND GROUP LOYALTY}

identity. However, in many European countries, there are so-called 'denizens' or 'quasi citizens' (Hammar, 1990), who are foreign citizens but have a permanent resident status with the related rights to work, to social security benefits, and to vote in local elections. This means that it is important to examine whether dual citizenship increases perceptions of national loyalty compared to foreign citizenship, or whether both are perceived and reacted to in similar ways.

Third, while most research on dual and gateway identities have focused on hierarchically nested identities (e.g., naturalized immigrants), dual citizenship represents two parallel identity categories (i.e., citizenship of two states). Previous research suggests that dominant identity category (i.e., foreign citizenship of an immigrant) might drive the evaluation of dual citizens (see Kang \& Bodenhausen, 2015), and that further stressing the connection of the dual identifier with the outgroup can be detrimental, particularly in the context of intergroup conflict (Levy, van Zomeren, Saguy, \& Halperin, 2017c). Considering the relatively strong debate about divided loyalties in the present research contexts, we assume that immigrants with dual citizenship might be viewed with the same suspicion as those who have foreign citizenship. This would mean that a dual legal status does not improve loyalty perceptions and therefore does not contribute to less bias toward immigrants.

However, it is also possible that a dual citizenship status makes the common national group rather than the foreign group membership salient and therefore leads to less bias compared to the perception of immigrants with only foreign citizenship (cf. Levy et al., 2017a,b). Thus, the present study can provide new insights on the consequences of being evaluated as a member of two groups with potentially conflicting interests. 


\section{PERCEIVED CITIZENSHIP AND GROUP LOYALTY}

\section{Aim and Hypotheses}

We test whether immigrants' citizenship status (national, dual, foreign) affects how majority members in Finland, Germany and the Netherlands perceive their national and foreign loyalties, and whether perceived loyalties are further associated with outgroup trust, support of immigrants' social influence, and acceptance of immigrants' in strategic positions. We focus on three outcomes that are especially relevant in the context of the debate about dual citizenship and immigrant integration. In addition to (dis)trust as a key outcome of perceived (dis)loyalty (cf., Kunst et al., 2018a), we examine support for immigrants'social participation by means of economic, media and policy-making influence (cf., Mepham \& Verkuyten, 2017) and the acceptance of immigrants in strategic positions (cf., Kunst et al., 2018a). This way, we can assess whether loyalty concerns related to dual citizenship have general negative intergroup consequences or are restricted to reluctance to see immigrants working in strategic positions with the potential to inflict damage to the nation.

The hypothesized model is displayed in Figure 1.

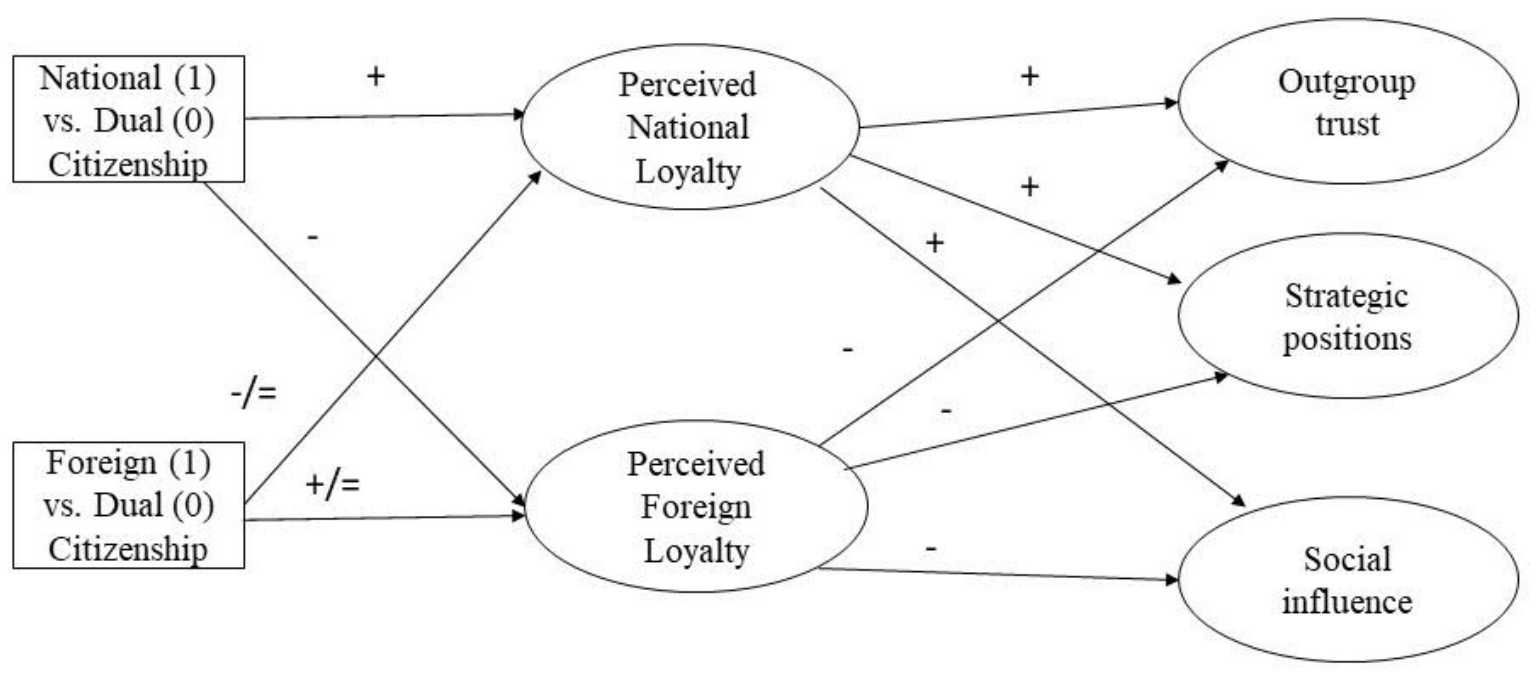

Figure 1. The Hypothesized Mediation Model 


\section{PERCEIVED CITIZENSHIP AND GROUP LOYALTY}

Based on theorization on gateway group members with hierarchically-nested identities reviewed above (e.g., Levy et al., 2017b), immigrants with national citizenship represent a gateway group and are thus expected to be perceived as having higher national loyalty. That, in turn, is expected to be associated with higher trust, acceptance and support for immigrants. In contrast, immigrants with foreign citizenship are expected to be regarded as outgroup members, resulting in lower perceived national loyalty (cf. Kunst et al., 2018a) and subsequently with lower trust, acceptance, and support.

Importantly, immigrants with dual citizenship can also be considered as gateway group members, but in a different way than naturalized immigrants, as dual citizenship concerns two non-nested or parallel group memberships. In the context of international rivalry between the EU and Russia and Turkey (see e.g., Verkuyten, 2018), immigrants with dual citizenship may be perceived as having lower national loyalty and higher foreign loyalty than immigrants with only national citizenship (cf. Levy et al., 2017a\&b; Kunst et al., 2018a). Further, research on cross-categorization has showed the detrimental effect of convergent categorization on ingroup bias and outgroup discrimination (Brewer, 2000; Marcus-Newhall, Miller, Holtz, \& Brewer, 1993). Therefore, majority group members may perceive an immigrant with dual citizenship to be simultaneously a member of an immigrant subgroup within a broader superordinate category of national citizens (i.e., naturalized immigrants), and a member of an outgroup (foreign citizens). In such a scenario, immigrants can be evaluated positively as ingroup members, but also negatively as outgroup members. Such duality may lead to higher intergroup differentiation and ambiguity, so that the dominant identity category (i.e., foreign citizenship of an immigrant) will drive the evaluation of dual citizens (see Kang $\&$ Bodenhausen, 2015). This could further lead to questioning of their national loyalty, due to people's tendency to avoid unnecessary risks to the well-being of their ingroup (see Kunst et al., 2018a). Thus, we will examine whether majority members perceive dual citizens as a gate-way group having higher national loyalty and lower foreign loyalty than immigrants with 


\section{PERCEIVED CITIZENSHIP AND GROUP LOYALTY}

only foreign citizenship, or whether majority members perceive dual citizens in a similar way as foreign citizens.

Finally, we should acknowledge that the meanings attributed to particular citizenship categories could vary not only as a function of target's perceived identity markers but also as a function of the perceiver's characteristics (Kang \& Bodenhausen, 2015), including the perceiver's own group identities (Pauker \& Ambady, 2009) and the context (Raijman, Davidov, Schmidt, \& Hochman, 2008). Thus, we also test our model by controlling for perceiver's national identification on the intergroup outcomes studied in three countries. Here, we focus on the feelings of pride as one important aspect of positive national identification (see, e.g., Mummendey, Klink, \& Brown, 2001). This kind of national attachment marks an emotional bond with the ingroup and can be considered as crucial from the viewpoint of perceived group loyalties and reactions to outgroups (Raijman et al., 2008).

Although all the three countries studied allow dual citizenship, there are several differences between them in terms of legislation and policy. Namely, Finland accepts dual citizenship with no demand for foreign citizens to renounce their former citizenships, unless the other country requires to do so. In contrast, Germany and the Netherlands generally discourage dual citizenship, though exceptions are made for the citizens of other EU countries and from other countries that make it difficult, if not impossible, to renounce citizenship. Due to the scarcity of previous research on dual citizenship in these contexts, we do not make any specific predictions concerning possible between-country differences.

\section{Method}

\section{Participants and Design}

A total of 1059 participants in Finland, the Netherlands and Germany took part in a study related to impression formation in the internet. One additional participant took part 


\section{PERCEIVED CITIZENSHIP AND GROUP LOYALTY}

in the Finnish study but did not give consent for using the data after debriefing and was therefore not included in our sample. Data of 119 participants $\left(n_{\text {Finland }}=4 ; n_{\text {Netherlands }}=52\right.$; $n_{\text {Germany }}=63$ ) were excluded before analyses, because of having ethnic minority background or foreign citizenship, and eleven participants were omitted from the Dutch sample as they indicated to be younger than 16 years.

In Finland, data were collected through an online study among university and open university students during several courses between 2016-2017. In the Netherlands, online data were collected using the ThesisTools platform which is similar to MTurk. In Germany, an online survey was conducted via the virtual laboratory of a distance learning university (in return for partial course credits in Psychology) and through social media. Before starting the data collection in Germany, the main research question was preregistered at https://aspredicted.org (\#6043). ${ }^{1}$ In all studies, participation was voluntary and anonymous.

Participants were randomly allocated to one of the three experimental conditions or one control condition. In each condition, participants were first presented with a LinkedIn profile of an immigrant-origin male (of a Russian background in Finland and Turkish background in the Netherlands and Germany). The profile (see Appendix 1) was constructed to represent a typical profile of a job seeker and included the name (Sergey/Mehmet), age (30 years old), country of birth (Russia/Turkey), current residence (Espoo, Finland / The Hague, the Netherlands / Hamburg, Germany), occupation (unemployed), education (Computer Information Systems), and a photo of the person. The names and the photos of the targets represented stereotypical members of the Russian and Turkish communities in the countries studied. The photos used in the profiles were acquired from an open internet database. In addition, the person's citizenship and the length of residence in the country (since 2005) was mentioned in the list of characteristics. The personal and demographic information of the

\footnotetext{
${ }^{1}$ Results for the preregistered research question and analyses are reported in Table 2 . However, for the current paper, it was decided to pool the data of the three countries for the analyses.
} 


\section{PERCEIVED CITIZENSHIP AND GROUP LOYALTY}

target person was the same, but citizenship varied between conditions: national citizenship (Finnish/Dutch/German), foreign citizenship (Russian/Turkish), dual citizenship (Finnish and Russian/Dutch and Turkish/German and Turkish). Citizenship of the evaluated target was displayed with national flag(s) and the name of the country (countries). In the control condition, no information of the target person's citizenship was presented in the profile. Participants were instructed to familiarize themselves with the LinkedIn profile displayed, and to answer a few questions regarding the profile. These attention check questions were used to make sure that the participants internalized the information presented in the profile.

After this task, all participants were given a brief introduction to the measures of the questionnaire, stating that they would be asked questions regarding their thoughts and feelings about people like the one presented in the LinkedIn profile. Upon completion of the questionnaire, participants were debriefed about the purpose of the study.

Across the three studies, 150 participants $\left(n_{\text {Finland }}=6 ; n_{\text {Netherlands }}=108 ; n_{\text {Germany }}\right.$ =36) were removed from the analyses for incorrectly indicating the citizenship of the target person in the attention check question. This resulted in a final sample of 779 participants $\left(n_{\text {Finland }}=174 ; n_{\text {Netherlands }}=377 ; n_{\text {Germany }}=228\right)$. Sensitivity analysis showed that with this sample, small effects of $f=0.12$ could be detected in the analysis at conventional significance levels (alpha $=.05,1-\beta=.80)$. In the final sample $(N=779)$, participants' age range was 18 55 years in Finland $(M=26, M o=21), 16-81$ years in the Netherlands $(M=38$, Mo $=19)$, and 18-62 years in Germany $(M=35, \mathrm{Mo}=23)$. The majority of the participants in all three countries were women (83.3 percent in Finland, 65.3 percent in the Netherlands and 66.2 percent in Germany). There were statistically significant country differences with respect to age, $\mathrm{H}(2)=70.53, p<.001$. Kruskal-Wallis post hoc comparison revealed that the participants were younger in the Finnish sample, compared to the Dutch and the German participants $(p s<.001)$. Furthermore, the samples differed with respect to gender, $\chi^{2}(2)=$ 


\section{PERCEIVED CITIZENSHIP AND GROUP LOYALTY}

$18.98, p<.001$, with a relative over-representation of women in the Finnish sample. In the experimental groups within the countries, the age distributions and ratios of males to females were equivalent. In total, there were 194 participants in the national citizenship condition, 129 in the foreign citizenship condition, 208 in the dual citizenship condition and 251 in the control condition.

\section{Measures}

All measures were assessed using a seven-point Likert scale $(1=$ strongly disagree/negative, 7 = strongly agree/positive) .

Perceived group loyalty was assessed by asking about the target's perceived psychological loyalty (two items adapted from Djupe, 2000) and perceived loyal behavior (five items adapted from Silver, 1997) toward the country of residence and the country of origin. Participants evaluated, how strongly they thought that people like Sergey/Mehmet: “...feel part of the [national/foreign] society?” and “... feel responsible for the [national/foreign] society?". For perceived loyal behavior, participants were asked how strongly they think that people like Sergey/Mehmet are willing to: "Risk their lives to defend the interests of [national/foreign country] and of the [national/foreign] people", "Follow the [national/foreign] rules and regulations", "Defend [national/foreign country] in public, even though this is controversial", "Vote for a [national/foreign] candidate at [country's] local elections", and "Criticize [national/foreign country] openly". We used the mean score of the items referring to the country of residence to construct the perceived national loyalty scale ( $\alpha$ $\geq .81)$ and the items referring to the country of origin to construct the perceived foreign loyalty scale $(\alpha \geq .81)$. On both scales, a higher score reflected higher perceived loyalty.

$$
\text { Outgroup trust was measured using the conceptualization by Hewstone and }
$$
colleagues (2008). Participants responded to the following three items: "Russians/Turks living 


\section{PERCEIVED CITIZENSHIP AND GROUP LOYALTY}

in [country] cannot always be trusted politically" (reversed item), "Most of Russians/Turks living in [country] are trustworthy", and "Russians/Turks living in [country] will not take advantage of us [national majority group] if we trust them". The scale was constructed by taking the mean score of these three items $(\alpha \geq .68)$ with a higher score reflecting more outgroup trust.

Acceptance in strategic positions was measured by asking participants to express their feelings when people of immigrant backgrounds, like Sergey in Finland or Mehmet in the Netherlands or Germany "have high ranking positions in the military", "have important political functions", "work for the national security service", and "play an important role in business". The scale was constructed by taking the mean score of these four items $(\alpha \geq .90)$ with a higher score reflecting higher acceptance of Russian/Turkish immigrants holding strategic positions in society.

Support for minority's social influence was assessed using three items adapted from a previous study by Verkuyten (2009, Study 3). Participants were asked to indicate the extent to which they think that people like Mehmet/Sergey: “... should be helped finding a job in [country]", “...should be heard more often in the [country's] media”, and "...should be more involved when it comes to important decision making in society". The scale was constructed by taking the mean scores of these items $(\alpha \geq .78)$ with a higher score reflecting more support for minorities' social influence.

National attachment was measured with a single item tapping national pride, an emotional bond with the national ingroup (Raijman et al., 2008). Participants were asked to indicate their agreement with the following statement: "I am proud to be a [Finn/Dutch/German]", with a higher score reflecting stronger national attachment.

\section{Measurement Model}




\section{PERCEIVED CITIZENSHIP AND GROUP LOYALTY}

We first conducted confirmatory factor analysis of the items in Mplus 8.1

(Muthén \& Muthén, 1998-2012) using robust maximum likelihood estimation to test our measurement model. We removed ${ }^{2}$ the items "Criticize [national/foreign country] openly" from the analyses, as these did not contribute substantially to the latent factors of national and foreign loyalty, $b \mathrm{~s}<.046, p s<.017$. Furthermore, we allowed the items "...feel part of the [national] society?" and “... feel responsible for the [national] society?", "risk their lives to defend the interests of [national country] and of the [national] people", and "risk their lives to defend the interests of [foreign country] and of the [foreign] people", and "have high ranking positions in the military" and "work for the national security service" to co-vary. The resulting measurement model had a good fit to the data, $\mathrm{CFI}=.923 ; \mathrm{TLI}=.909 ; \mathrm{RMSEA}=$ $.063[90 \% \mathrm{CI}=.059-.068], p<.001 ; \mathrm{SRMR}=.054$.

Subsequently, we examined whether our proposed five-factor solution presented a better fit to the data in comparison to a four-factor solution with perceived loyalties loaded on one factor or all dependent variables arranged as part of a higher order factor of attitudinal reactions. We established that the five-factor solution had a better model fit in comparison to all other theoretically logical combinations. Therefore, we can conclude that perceived national loyalty, perceived foreign loyalty, outgroup trust, acceptance in strategic positions, and support for immigrants' social influence are empirically distinct constructs (see also Table 1).

Finally, we tested for measurement invariance across the three countries with a forward selection. First, we analyzed the configural invariance model that is the least restrictive model with all factor loadings, intercepts, and residual variances allowed to vary across countries $(\mathrm{CFI}=.914 ; \mathrm{TLI}=.899 ; \mathrm{RMSEA}=.069[90 \% \mathrm{CI}=.064-.074], p<.001 ;$ SRMR $=.066)$. Second, we ran a metric model with only intercepts and residual variances

\footnotetext{
${ }^{2}$ The Cronbach's alphas reported above refer to the final scales not including these two items.
} 


\section{PERCEIVED CITIZENSHIP AND GROUP LOYALTY}

allowed to vary across countries $(\mathrm{CFI}=.910 ; \mathrm{TLI}=.900 ; \mathrm{RMSEA}=.069[90 \% \mathrm{CI}=.064-$ $.073], p<.001 ;$ SRMR $=.073)$. A covariance was freed between “... feel responsible for the [national] society?" and “... feel responsible for the [foreign] society?", achieving a model fit that was not worse than the configural model $(\mathrm{CFI}=.916 ; \mathrm{TLI}=.906 ; \mathrm{RMSEA}=.066[90 \%$ $\left.\mathrm{CI}=.062-.071], p<.001 ; \mathrm{SRMR}=.074, \Delta \chi^{2}(31)=16.0754, p=.986\right)$ thus allowing us to proceed to test for scalar invariance with only residual variances allowed to be free across groups. The scalar model had an acceptable model fit $(\mathrm{CFI}=.884 ; \mathrm{TLI}=.877 ; \mathrm{RMSEA}=$ $.076[90 \% \mathrm{CI}=.071-.080], p<.001 ; \mathrm{SRMR}=.085)$. After freeing one more covariance between perceived loyalty measures (“...feel responsible the [foreign] society?” and "...feel part of the [foreign] society?") and the intercepts of two items; one on perceived foreign loyalty (“...feel responsible for the [foreign] society?”) and another item on outgroup trust ("Russians/Turks living in [country] will not take advantage of us [national majority group] if we trust them"), a partial scalar model was achieved $(\mathrm{CFI}=.915 ; \mathrm{TLI}=.908 ; \mathrm{RMSEA}=.066$ $[90 \% \mathrm{CI}=.061-.070], p<.001 ; \mathrm{SRMR}=.081)$. This resulted in a model fit that was not

significantly worse than that of the metric model $\left(\Delta \chi^{2}(27)=31.3417, p=.257\right)$ thus allowing us to make cross-country comparisons. 


\section{PERCEIVED CITIZENSHIP AND GROUP LOYALTY}

Table 1

Measurement Model for the Five Factors of Perceived Loyalties, Outgroup Trust, Acceptance of Strategic Positions and Support for Immigrants' Social Influence $(\mathrm{MLR}, N=779)$

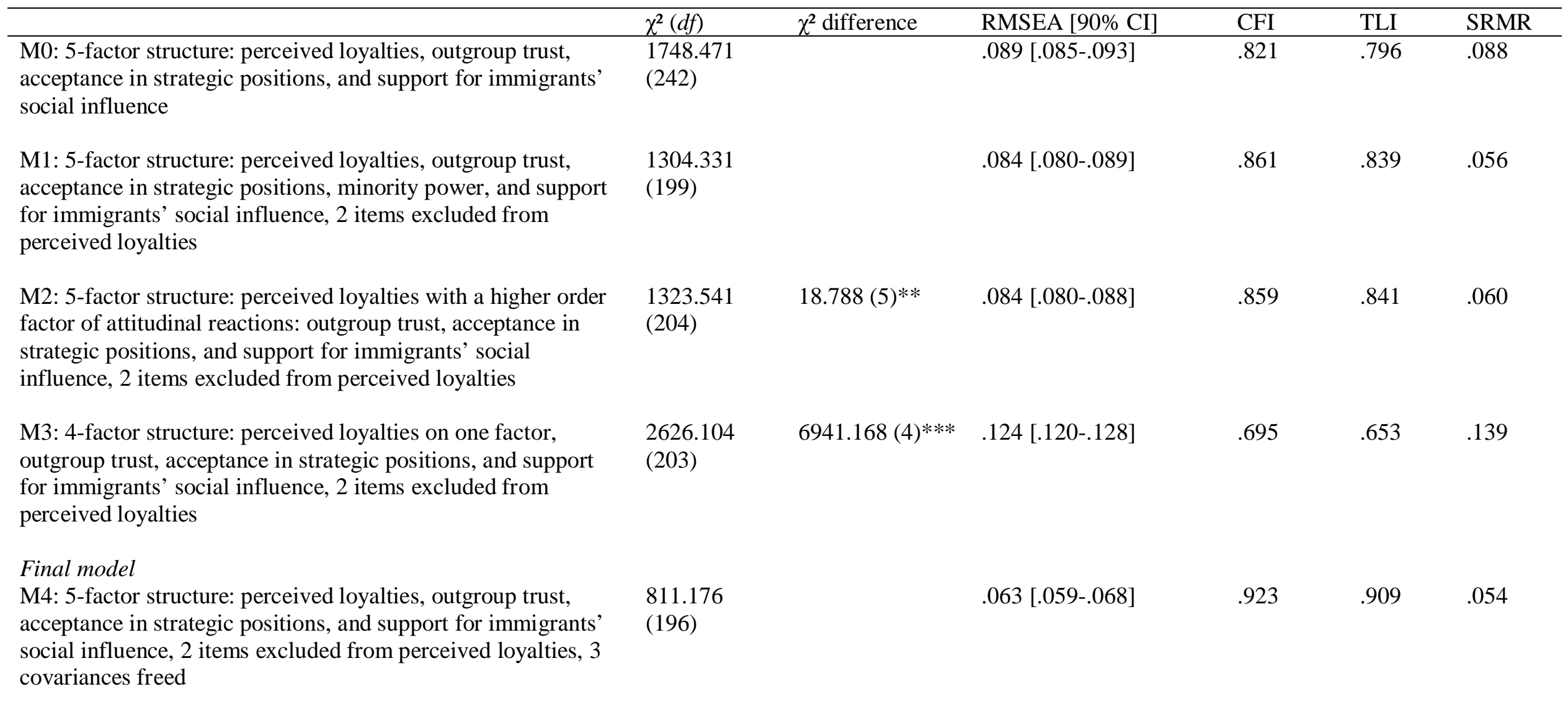

Note. Chi-square difference tests are computed in comparison to M1. $* * * p<.001, * * p<.01$. 


\section{Results}

Descriptive Results

Table 2 presents the means for the variables per condition. We first assessed whether there were within-condition differences regarding the participants' perception of the target's national and foreign loyalty. In the control $(t(250)=3.48, p=.001)$, dual $(t(207)=$ 5.37, $p=.001)$, and foreign citizenship $(t(128)=6.18, p<.001)$ conditions, participants evaluated the foreign loyalty of the target as higher than their national loyalty. Only in the national citizenship condition, participants perceived the target as having higher levels of national loyalty in comparison to foreign loyalty $(t(190)=-2.78, p=.006)$.

As regards to differences between conditions, perceived national loyalty of the target was higher among participants in the national citizenship condition, as compared to participants in the foreign and dual citizenship conditions and the control condition where no information about the target's citizenship was given. Additionally, participants in the foreign citizenship condition perceived national loyalty of the target as significantly lower than participants in the other conditions. Regarding perceived foreign loyalty, participants in the national condition perceived the target to have lower foreign loyalty compared to the dual, foreign and control conditions. The perceived trustworthiness of the target did not differ among the three experimental conditions, but participants in the control condition reported lower levels of perceived trustworthiness of the target than participants in the national citizenship condition. Additionally, participants in the foreign citizenship condition were significantly less likely to support minorities in strategic positions, compared to national and dual citizenship conditions. Finally, no significant differences between the conditions were found with respect to the support for the social influence of immigrants. Although the mean scores of the variables differed between the countries (except for support for minorities in 


\section{PERCEIVED CITIZENSHIP AND GROUP LOYALTY}

strategic positions, see the footer of Table 2), the pattern of results between the experimental conditions was the same across countries, as there were no significant interactions between country and condition $\left(F_{\mathrm{s}}<1.165 ; p \mathrm{~s}>.323\right)$.

Table 2

Means and Standard Deviations of Core Variables per Condition, Controlled for Country and the Condition x Country Interaction

\begin{tabular}{llllll}
\hline $\begin{array}{l}\text { Citizenship } \\
\text { Condition }\end{array}$ & $\begin{array}{l}\text { National } \\
\text { Loyalty }^{\mathrm{a}}\end{array}$ & $\begin{array}{l}\text { Foreign } \\
\text { Loyalty }^{\mathrm{b}}\end{array}$ & $\begin{array}{l}\text { Outgroup } \\
\text { Trust }^{\mathrm{c}}\end{array}$ & $\begin{array}{l}\text { Strategic } \\
\text { Position }^{\mathrm{d}}\end{array}$ & $\begin{array}{l}\text { Social } \\
\text { Influence }^{\mathrm{e}}\end{array}$ \\
\hline Control & $3.96_{\mathrm{a}}(1.02)$ & $4.36_{\mathrm{a}}(1.17)$ & $4.53_{\mathrm{a}}(1.37)$ & $4.51_{\mathrm{ab}}(1.47)$ & $4.49_{\mathrm{a}}(1.43)$ \\
Dual & $3.91_{\mathrm{a}}(0.99)$ & $4.49_{\mathrm{a}}(1.08)$ & $4.63_{\mathrm{ab}}(1.27)$ & $4.56_{\mathrm{b}}(1.41)$ & $4.51_{\mathrm{a}}(1.57)$ \\
National & $4.32(0.92)$ & $4.01(1.14)$ & $4.92_{\mathrm{b}}(1.17)$ & $4.79_{\mathrm{b}}(1.40)$ & $4.81_{\mathrm{a}}(1.41)$ \\
Foreign & $3.59(0.91)$ & $4.44_{\mathrm{a}}(1.13)$ & $4.71_{\mathrm{ab}}(1.18)$ & $4.09_{\mathrm{a}}(1.28)$ & $4.56_{\mathrm{a}}(1.24)$ \\
& & & & & \\
Total & $3.97(1.00)$ & $4.32(1.15)$ & $4.68(1.27)$ & $4.52(1.42)$ & $4.59(1.44)$ \\
\hline
\end{tabular}

Note. For each variable, mean scores with the same subscript indicate no significant differences between the conditions (Scheffé's posthoc comparisons, $p>.05$ ). Superscripts, in turn, refer to tests of differences between countries:

${ }^{a}$ National loyalty differed between the three countries, $F(2,766)=12.110, p<.001, \eta^{2}=.03$. Scheffé's posthoc comparisons showed that perceived national loyalty was higher in Finland compared to the Netherlands and Germany. There was no significant interaction between country and condition, $F(6,766)=0.407, p=.875$.

${ }^{\mathrm{b}}$ Foreign loyalty differed between the three countries, $F(2,766)=13.968, p<.001, \eta^{2}=.04$. Scheffé's posthoc comparisons showed that perceived foreign loyalty was lower in Finland compared to the Netherlands and Germany. There was no significant interaction between country and condition, $F(6,766)=0.881, p=.509$.

${ }^{c}$ Perceived trustworthiness differed between the three countries, $F(2,766)=13.123, p<.001, \eta^{2}$ $=.03$. Scheffé's posthoc comparisons showed that perceived trustworthiness was higher in Finland compared to the Netherlands and Germany. There was no significant interaction between country and condition, $F(6,766)=0.835, p=.543$.

${ }^{\mathrm{d}}$ Support for minorities in strategic positions did not differ between the three countries, $F(2,766)$ $=.055, p=.947$. There was no significant interaction between country and condition, $F(6,766)=$ $0.619, p=.715$.

e Support for the social influence of minorities differed between the three countries, $F(2,766)=$ $30.605, p<.001, \eta^{2}=.08$. Scheffé's posthoc comparisons showed that support was lower in the Netherlands compared to Finland and Germany. There was no significant interaction between country and condition, $F(6,766)=1.165, p=.323$. 


\section{PERCEIVED CITIZENSHIP AND GROUP LOYALTY}

In line with our expectations, bivariate correlations (Table 3) showed that across conditions, perceived national loyalty was associated with more positive attitude toward the immigrant group, whereas perceived foreign loyalty was generally associated with a more negative stance. Only the association between perceived foreign loyalty and support for immigrant's social influence in the foreign citizenship condition did not reach statistical significance.

Table 3

Bivariate Correlations Between the Core Variables per Condition

\begin{tabular}{|c|c|c|c|c|c|}
\hline & $\begin{array}{l}\text { Citizenship } \\
\text { Condition }\end{array}$ & $\begin{array}{l}\text { Foreign } \\
\text { Loyalty }\end{array}$ & $\begin{array}{l}\text { National } \\
\text { Loyalty }\end{array}$ & Trust & $\begin{array}{l}\text { Strategic } \\
\text { Position }\end{array}$ \\
\hline \multirow[t]{4}{*}{ National Loyalty } & Control & $-.30 * * *$ & & & \\
\hline & Dual & $-.15^{*}$ & & & \\
\hline & National & $-.19 * *$ & & & \\
\hline & Foreign & $-.22 * * *$ & & & \\
\hline \multirow[t]{4}{*}{ Trust } & Control & $-.44 * * *$ & $.50 * * *$ & & \\
\hline & Dual & $-.36^{* * *}$ & $.54 * * *$ & & \\
\hline & National & $-.45^{* * * *}$ & $.37 * * *$ & & \\
\hline & Foreign & $-.22 *$ & $.40 * * *$ & & \\
\hline \multirow[t]{4}{*}{ Strategic Position } & Control & $-.22 * * *$ & $.48 * * *$ & $.61 * * *$ & \\
\hline & Dual & $-.28 * * *$ & $.48 * * *$ & $.59 * * *$ & \\
\hline & National & $-.29 * * *$ & $.43 * * *$ & $.51 * * *$ & \\
\hline & Foreign & $-.25 * *$ & $.54 * * *$ & $.56 * * *$ & \\
\hline \multirow[t]{4}{*}{ Social Influence } & Control & $-.20 * *$ & $.44 * * *$ & $.50 * * *$ & $.50 * * *$ \\
\hline & Dual & $-.30 * * *$ & $.43 * * *$ & $.52 * * *$ & $.50 * * *$ \\
\hline & National & $-.15 * *$ & $.39 * * *$ & $.34 * * *$ & $.46^{* * *}$ \\
\hline & Foreign & -.11 & $.42 * * *$ & $.46^{* * *}$ & $.60 * * *$ \\
\hline
\end{tabular}




\section{PERCEIVED CITIZENSHIP AND GROUP LOYALTY}

\section{Main Results}

Because the descriptive findings for the dual citizenship condition were similar to the control condition, we compared the effects of dual vs. national and dual vs. foreign citizenship on perceived group loyalties and the three outcome measures in the following analyses. First, we examined whether the pattern of associations is similar in the three countries. Results of a multi-group comparison showed, that the structural model could be constrained to be similar across the three countries without leading to a worse fitting model, $\Delta \chi^{2}(32)=27.96, p=.671$. This means that the same pattern of associations was found in all three countries.

To test our hypotheses, we constructed a path model in Mplus 8.2 (Muthén \& Muthén, 1998-2012), including national and foreign citizenship conditions as two independent variables with dual citizenship condition as the reference category. Perceived national and foreign loyalties were included as mediators, and outgroup trust, acceptance of minorities in strategic positions, and support for minority's social influence were included as dependent variables. The results of the path model are presented in Table 4 and Figure 2 and the model fit was acceptable $(\mathrm{CFI}=.897 ; \mathrm{TLI}=.891 ; \mathrm{RMSEA}=.068[90 \% \mathrm{CI}=.062-.073], p<.001 ;$ SRMR = .092). In line with the predictions, compared to participants in the dual citizenship condition, those in the national citizenship condition were perceived as having higher national loyalty, $b=.36(.09), p<.001$, and lower foreign loyalty, $b=-.33(.09), p<.001$. Participants in the foreign citizenship condition, on the other hand, were perceived as having lower national loyalty than participants in the dual citizenship condition, $b=-.24(.10), p=.019^{3}$, but there was no difference in perceived foreign loyalty between the foreign and dual citizenship conditions $b=.08(.10), p=.385$.

\footnotetext{
${ }^{3}$ In this paper we report the results of the constrained model, but we also assessed the results of the unconstrained model. We found that although the direction of association was similar in all countries, the direct association between the foreign condition and trust was only significant in Finland. The unconstrained results are available upon request.
} 


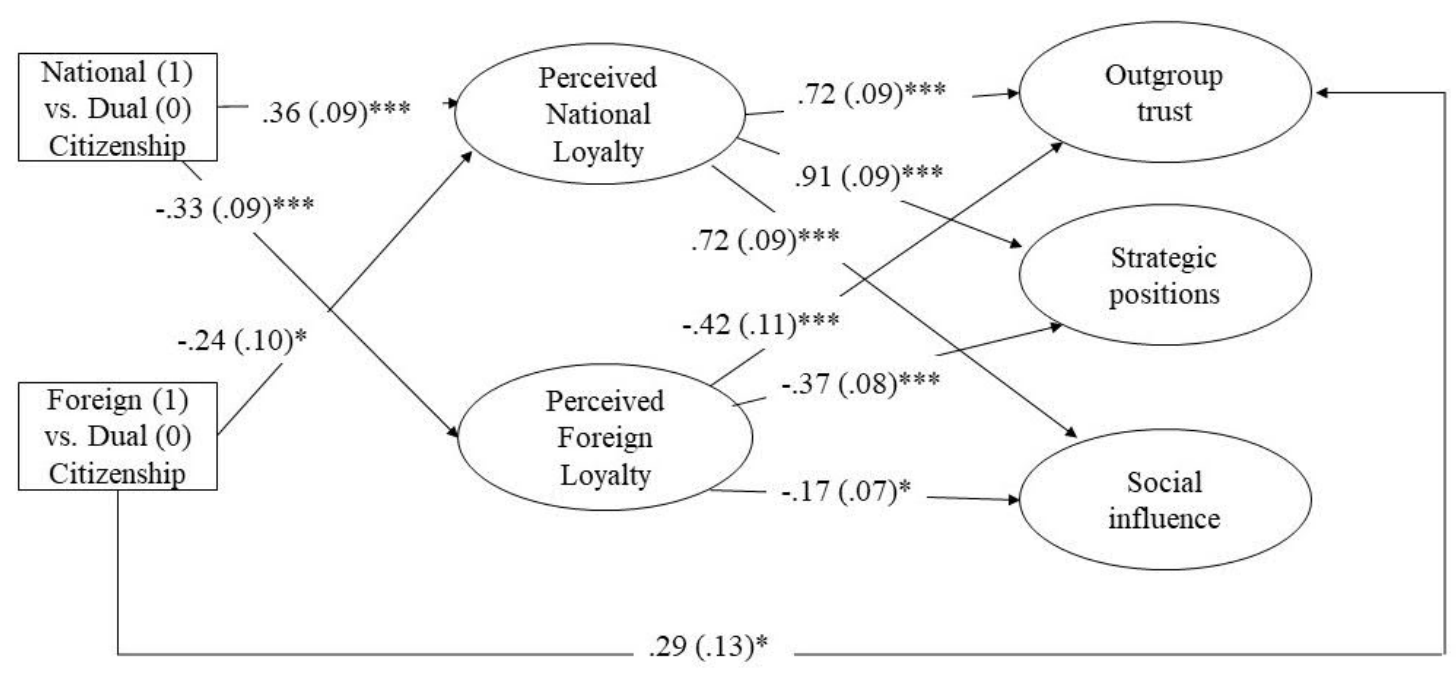

Figure 2. Mediation Model for the Effect of Citizenship on Outgroup Trust, Support of Immigrants' Social Influence, and Acceptance of Immigrants in Strategic Positions Mediated by Perceived National and Foreign Loyalty

The experimental manipulation had no direct effect on the dependent variables (national citizenship condition on trust $b=-.14(.11), p=.225$, strategic position $b=-.20$ (.13), $p=.104$, social influence $b=-.09(.12), p=.449$; foreign citizenship condition on strategic position $b=-.16(.14), p=.247$, social influence $b=.03(.13), p=.816)$, except that participants in the foreign citizenship condition (in comparison to dual citizenship condition) showed higher levels of outgroup trust, $b=.29(.13), p=.025$. However, perceived national and foreign loyalty were significantly associated with the three outcome measures (Table 4). Perceived national loyalty was associated with higher levels of outgroup trust $b=.72(.09), p$ $<.001$, higher acceptance of minorities in strategic positions $b=.91(.09), p<.001$, and more support for their social influence $b=.72(.09), p<.001$. Perceived foreign loyalty, in turn, predicted lower levels of outgroup trust $b=-.42(.11), p<.001$, lower acceptance of minorities in strategic positions $b=-.37(.08), p<.001$, and less support for their social influence $b=-.17(.07), p=.012$. To assess the indirect effects of citizenship category 


\section{PERCEIVED CITIZENSHIP AND GROUP LOYALTY}

membership, a percentile CI bootstrap with an estimation of 1000 replications with $95 \%$ bias confidence intervals was conducted. Indirect effects are considered significant when zero does not fall in-between the confidence interval (Preacher \& Hayes, 2008).

The hypothesized indirect effects of perceived national and foreign loyalty were found only in the case of the national citizenship condition (see Table 5) in which higher levels of outgroup trust, $b=.26(.07), 95 \% \mathrm{CI}[.081, .450]$, higher acceptance of minorities in strategic positions, $b=.32(.08), 95 \%$ CI $[.117, .533]$, and more support for their social influence, $b=$ $.26(.07), 95 \%$ CI $[.086, .428]$, could be explained by their higher levels of perceived national loyalty (in comparison to the participants in the dual citizenship condition). Their higher levels of outgroup trust, $b=.14(.05), 95 \%$ CI $[.046, .290]$, higher acceptance of minorities in strategic positions, $b=.12(.04), 95 \% \mathrm{CI}[.033, .252]$, and more support for their social influence, $b=.06(.07), 95 \%$ CI $[.000, .145]$ (marginal) could also be explained by their lower levels of perceived foreign loyalty.

Finally, we tested the model with national attachment included as a covariate in the analyses controlling for single-item measurement error. The model fit was comparable $(\mathrm{CFI}=$ $.896 ; \mathrm{TLI}=.890 ; \mathrm{RMSEA}=.066[90 \% \mathrm{CI}=.060-.071], p<.001 ; \mathrm{SRMR}=.091)$ and the results resembled the ones reported above, with the significant associations remaining the same. National attachment was only associated with higher perceived foreign loyalty, $b=.11$ (.34), $p=.001$. 
PERCEIVED CITIZENSHIP AND GROUP LOYALTY

Table 4

Results of Path Analyses

\begin{tabular}{|c|c|c|c|c|c|c|c|c|c|c|c|c|c|c|c|}
\hline & \multicolumn{3}{|c|}{ Trust } & \multicolumn{3}{|c|}{$\begin{array}{l}\text { Strategic } \\
\text { Position }\end{array}$} & \multicolumn{3}{|c|}{ Social Influence } & \multicolumn{3}{|c|}{ National Loyalty } & \multicolumn{3}{|c|}{ Foreign Loyalty } \\
\hline & $b$ & $(s e)$ & B & $b$ & $(s e)$ & B & $b$ & $(s e)$ & $\beta$ & $b$ & $(s e)$ & $\beta$ & $b$ & $(s e)$ & ß \\
\hline \multicolumn{16}{|c|}{ Citizenship (ref.: dual) } \\
\hline National & -.14 & $(.11)$ & -.07 & -.20 & $(.13)$ & -.07 & -.09 & $(.12)$ & -.04 & .36 & $(.09) * * *$ & $.25 * * *$ & -.33 & $(.09) * * *$ & $-.22 * * *$ \\
\hline National loyalty & .72 & $(.09) * * *$ & $.54 * * *$ & .91 & $(.09) * * *$ & $.46 * * *$ & .72 & $(.09) * * *$ & $.50 * * *$ & & & & & & \\
\hline Foreign loyalty & -.42 & $(.11)^{* * *}$ & $-.33 * * *$ & -.37 & $(.08)^{* * *}$ & $-.20 * * *$ & -.17 & $(.07)^{*}$ & $-.12 *$ & & & & & & \\
\hline
\end{tabular}
Note: $* * * p<.001 ; * * p<.01 ; * p<.05$.

Table 5

Unstandardized Results Regarding Indirect Effects

\begin{tabular}{|c|c|c|c|c|c|c|c|c|c|}
\hline & \multicolumn{3}{|l|}{ Trust } & \multicolumn{3}{|c|}{ Strategic Position } & \multicolumn{3}{|c|}{ Social Influence } \\
\hline & $B$ & (se) & $(95 \% \mathrm{CI})$ & $b$ & (se) & $(95 \% \mathrm{CI})$ & $b$ & $(\mathrm{se})$ & $(95 \% \mathrm{CI})$ \\
\hline Citizenship (ref.: dual) & & & & & & & & & \\
\hline National via National loyalty & .26 & $(.07)$ & $(.081, .450)$ & .32 & $(.08)$ & $(.117, .533)$ & .26 & $(.07)$ & $(.086, .428)$ \\
\hline National via Foreign loyalty & .14 & $(.05)$ & $(.046, .290)$ & .12 & $(.04)$ & $(.033, .252)$ & .06 & $(.03)$ & $(.000, .145)$ \\
\hline Foreign via National loyalty & -.17 & $(.07)$ & $(-.361, .013)$ & -.22 & $(.09)$ & $(-.481, .015)$ & -.17 & $(.07)$ & $(-.405, .010)$ \\
\hline Foreign via Foreign loyalty & -.04 & $(.04)$ & $(-.175, .071)$ & -.03 & $(.04)$ & $(-.154, .067)$ & -.01 & $(.02)$ & $(-.078, .034)$ \\
\hline
\end{tabular}


PERCEIVED CITIZENSHIP AND GROUP LOYALTY

Table 6

Standardized Results Regarding Indirect Effects

\begin{tabular}{llll|lll|lll}
\hline & \multicolumn{3}{c|}{ Trust } & & \multicolumn{2}{|c|}{ Strategic Position } & & \multicolumn{2}{l}{ Social Influence } \\
& $\beta$ & $(S E)$ & $(95 \% \mathrm{CI})$ & $\beta$ & $(S E)$ & $(95 \% \mathrm{CI})$ & $(S E)$ & $(95 \% \mathrm{CI})$ \\
\hline Citizenship (ref.: dual) & & & & & & & & & \\
National via National loyalty & .13 & $(.04)$ & $(.039, .233)$ & .11 & $(.03)$ & $(.040, .191)$ & .12 & $(.03)$ & $(.041, .204)$ \\
National via Foreign loyalty & .07 & $(.02)$ & $(.023, .146)$ & .04 & $(.02)$ & $(.012, .088)$ & .03 & $(.01)$ & $(.000, .071)$ \\
Foreign via National loyalty & -.09 & $(.04)$ & $(-.194, .006)$ & -.07 & $(.03)$ & $(-.169, .004)$ & -.08 & $(.03)$ & $(-.176, .005)$ \\
Foreign via Foreign loyalty & -.02 & $(.02)$ & $(-.088, .034)$ & -.01 & $(.01)$ & $(-.046, .022)$ & -.01 & $(.01)$ & $(-.037, .015)$ \\
\hline
\end{tabular}




\section{PERCEIVED CITIZENSHIP AND GROUP LOYALTY}

\section{Discussion}

We investigated whether immigrants' citizenship status (national, dual or foreign citizenship) was associated with perceived national and foreign loyalty, and thereby with outgroup trust, the acceptance of immigrants in strategic positions and immigrants having social influence. Previous research has demonstrated that minority members and immigrants who express dual selfidentification are evaluated more negatively compared to those who solely self-identify with the shared national category, and that perceived divided loyalties underlie majority members' bias toward dual self-identifiers (Kunst et al., 2018a). We tried to go beyond this research in three ways: (1) by focusing on the largely neglected identity marker of citizenship, (2) by acknowledging all three forms of immigrants' citizenship, including foreign citizenship, and (3) by complementing previous research on nested dual identities with a focus on parallel dual identities (i.e., citizenship of two states).

We found that when the immigrant target possessed only national citizenship, he was perceived as more loyal towards the country of residence than towards the country of origin. In contrast, an immigrant with foreign citizenship was perceived to be more loyal toward the country of origin than country of residence. However, we were particularly interested in majority group members' perceptions of and reactions toward immigrants with dual citizenship. As dual citizenship accentuates both majority and minority group memberships, not only those possessing national citizenship, but also immigrants with dual citizenship may be seen as bridges between their two reference groups. This, in turn, may result in positive evaluation (cf., Levy et al., 2017a,b), or create category-related ambiguity resulting in negative evaluation (cf., Brewer, 2000).

Indeed, speaking for this duality, our results showed that the perceived national loyalty of immigrants with dual citizenship was higher than that of immigrants with only foreign citizenship. However, the foreign loyalty of dual citizens was perceived to be as high as that of foreign citizens. Higher foreign loyalty was further associated with distrust, reluctance to accept this 


\section{PERCEIVED CITIZENSHIP AND GROUP LOYALTY}

dual citizen in strategic positions, and lower support for their social influence. Majority members thus tended to trust immigrants, accept immigrants in strategic positions and support their social influence only when they had single national citizenship of the country of residence.

These results show the potential of dual citizens to alleviate intergroup bias as compared to immigrants with single foreign citizenships, but they also suggest that this potential is limited as compared to single national citizenship. As its main contribution, this study suggests that gateway group membership is an asset in hierarchically nested identities (e.g., naturalized immigrants, national minorities) as is the typical case in Levy's and colleagues' (2017) studies. When multiple identities are parallel at the same level of comparison and represent convergent categorization, ingroup bias and outgroup discrimination occur (see Brewer, 2000; Marcus-Newhall et al., 1993). As pointed out by Kang and Bodenhausen (2015), evaluation of targets belonging to several categories is a perceptual challenge, which may be resolved by letting one salient category dominate over others. Thus, based on our results it seems that foreign citizenship drives the evaluation of dual citizens, while their membership in the national ingroup is suppressed.

In the present study, majority members perceived and reacted toward dual citizens in a similar way as when no citizenship status was indicated (control condition). This was not due to a failure of the experimental manipulation to make dual citizenship salient, as all participants included in the analysis correctly recognized that the immigrant target was a dual citizen. Rather, probably due to the lack/uncertainty/ambiguity of information received, in both of these conditions majority participants could not determine whether the target was an in- or and outgroup member (see Kang \& Bodenhausen, 2015). From the perspective of functional error-management (for discussion, see Kunst et al., 2018a), it seems plausible that in both of these conditions, majority group members tried to minimize the risk of trusting an outgroup member.

Indeed, the perceiver's own group membership (Kang \& Bodenhausen, 2015; Pauker \& Ambady, 2009) and the prevailing intergroup relations in the contexts studied should be 


\section{PERCEIVED CITIZENSHIP AND GROUP LOYALTY}

acknowledged, as they can be expected to affect the degree of perceived group loyalties of dual citizens (see also Brewer, 1999). In previous research, disloyalty concerns are found to be especially pronounced under conditions of intergroup threat from rival groups (Kunst et al., 2018a, Study 5). Immigrants can be even seen as a 'fifth column' that is loyal to the country of origin and tries to undermine the nation from within (Kunst et al., 2018a; Shadid, 2006; Sniderman \& Hagendoorn, 2007). Relations between Europe and Russia/Turkey have been challenging, and while Finland has a history of conflicts and occupations with Russia, Germany and the Netherlands are increasingly concerned about the political influence of the Turkish government on Turkish emigrants (Verkuyten, 2018). Thus, it is understandable that dual citizenship did not make immigrants from these countries appear as trusted gateway group members.

It is noteworthy that despite the differences in the samples and national policies regarding naturalization and immigrant integration, the pattern of findings was similar across the three countries. Given that most majority group members are probably not very familiar with the national legislation concerning dual citizenship, it seems plausible that general social categorization processes rather than country-specific policies drive people's perceptions of dual citizens and their group loyalties. Moreover, also higher national attachment of majority group members was associated with perceiving higher foreign loyalty of immigrants in all countries studied. This might be due to the fact that all the three countries represented nation states, in which majority's national identity could be perceived as being threatened by immigration and immigrants' naturalization (see, e.g., Riek, Mania, \& Gaertner, 2006). However, as a study by Raijman and colleagues (2008) shows, the effects of national attachment (i.e., pride) and subsequent threat perceptions on willingness to grant citizenship rights can also vary between nation states. Thus, our results do not exclude the possibility that also dual citizens might build 'bridges', and similarly to single national citizens, stimulate positive intergroup relations in contexts where the relationship between the respective states is positively interdependent, group identities are less politicized, or when minority 


\section{PERCEIVED CITIZENSHIP AND GROUP LOYALTY}

groups are perceived as an indispensable part of national superordinate category (e.g., Verkyten, Martinovic, \& Smeekes, 2014). This is something for future cross-cultural research to look into.

\section{Limitations and Conclusion}

There are three limitations that provide directions for future research. First, survey experiments allow testing of causal relations but are not optimal for testing mediational models or for studying real-life intergroup relations. One previous experimental study has demonstrated that perceived loyalty does drive the intergroup outcomes (Kunst et al., 2018a, Study 4), but more experimental and longitudinal research is needed to determine whether perceived loyalties do indeed have a causal effect on attitudinal reactions toward immigrants.

Second, national attachment was used in this study as predictor of perceived group loyalties and intergroup attitudes (cf. Verkuyten, 2009, on the relationship between ingroup identification, perceived threats and minority support). However, ingroup identification may also moderate the effects of perceived citizenship on group loyalties and intergroup attitudes (e.g., Crisp $\&$ Beck, 2005). Moreover, national identification was measured only with a single item tapping the pride aspect of national attachment (Raijman et al., 2008). Future studies need to better account for the effects of other emotional components of ingroup identification (e.g., glorification and superiority) and the potentially dual (direct and moderator) effects of ingroup identification on intergroup cognitions, attitudes and behaviors.

Third, the measure of support for immigrants in strategic positions was developed for this study, and some of the other scales were adjusted from studies conducted in other fields of research. Future research should examine the robustness of our findings across other measures of group loyalty, national identification, support for minorities in powerful positions and majority's willingness to act on behalf of minorities. 


\section{PERCEIVED CITIZENSHIP AND GROUP LOYALTY}

Furthermore, while we focused on citizenship status and perceived loyalty, future studies might examine loyalty concerns and other intergroup implications of (dual) citizenship in relation to immigrants' perceived motivations to naturalize. More practically vs. politically oriented motivations for citizenship acquisition (see e.g., Ronkainen, 2011) might differently affect majority members' perceived (dis)loyalty of dual citizens and their acceptance and support of immigrant's social influence and involvement.

Finally, we would like to call for future research on perceived threats evoked by dual citizens. While most previous research on dual identities has focused on hierarchically nested identities, the present study focused on parallel dual identities. We argue that these different types of dual identities might evoke different kinds of intergroup threats. For example, hierarchically nested dual identities may pose a threat to the positive distinctiveness of the ingroup (e.g., Hornsey \& Hogg, 2000), while simultaneous membership in two parallel political groups may evoke threats to the security, material well-being or cultural way of life of the ingroup (Riek et al., 2006), if the outgroup membership drives the evaluation of the dual group member (Kang \& Bodenhausen, 2015) and there is no sense of common identity that would alleviate threats to the integrity of the nation (Raijman et al., 2008).

In conclusion, citizenship is a major determinant of people's rights and a force of justice, equality and national cohesion. Therefore, we think that more social psychological research is needed on this central axis of stratification in many democratic societies. Turning immigrants into fellow citizens can promote their socio-political integration (Hainmueller, Hangartner, \& Pietrantuono, 2015, 2017) but it can also raise suspicions about divided loyalties. As a result, immigrants with dual citizenship can come to feel second-class citizens, if they are treated with double standards and their legally granted citizenship is considered as something that should be “earned” by demonstrating national loyalty and pride (Conover, Searing, \& Crewe, 2004). 


\section{PERCEIVED CITIZENSHIP AND GROUP LOYALTY}

\section{References}

Bloemraad, I. (2015). Theorizing and analyzing citizenship in multicultural societies. The Sociological Quarterly, 56(4), 591-606. doi: 10.1111/tsq.12095

Brewer, M. B. (2000). Reducing Prejudice Through Cross-Categorization: Effects of Multiple Social Identities. In S. Oskamp (Ed.), Reducing prejudice and discrimination (pp. 165-185). Hove: Psychology Press.

Centraal Bureau voor de Statistiek (2011, May 2). Brede steun voor beperking van dubbele nationaliteit (Broad support for limiting dual citizenship). Retrieved from https://www.cbs.nl/nl-nl/nieuws/2011/18/brede-steun-voor-beperking-dubbele-nationaliteit

Conover, P. J., Searing, D. D., \& Crewe, I. (2004). The elusive ideal of equal citizenship: Political theory and political psychology in the United States and Great Britain. The Journal of Politics, 66(4), 1036-1068. doi: 10.1111/j.1468-2508.2004.00289.x

Crisp, R. J., \& Beck, S. R. (2005). Reducing intergroup bias: The moderating role of ingroup identification. Group Processes \& Intergroup Relations, 8(2), 173-185. doi: $10.1177 / 1368430205051066$

Crisp, R. J., \& Hewstone, M. (2000). Multiple categorization and social identity. In D. Capozza \& R. Brown (Eds.), Social identity processes: Trends in theory and research (pp. 149-166). Beverly Hills: Sage.

Djupe, P. A. (2000). Religious Brand Loyalty and Political Loyalties. Journal for the Scientific Study of Religion, 39(1), 78-89.

Dovidio, J. F., Gaertner, S. L., \& Saguy, T. (2008). Another view of "we": Majority and minority group perspectives on a common ingroup identity. European Review of Social Psychology, 18(1), 296-330. doi: 10.1080/10463280701726132

Faist, T., Gerdes, J., \& Rieple, B. (2004). Dual Citizenship as a Path-Dependent Process. International Migration Review, 38(3), 913-944. 


\section{PERCEIVED CITIZENSHIP AND GROUP LOYALTY}

Hainmueller, J., Hangartner, D., \& Pietrantuono, G. (2015). Naturalization fosters the long-term political integration of immigrants. Proceedings of the National Academy of Sciences, 112(41), 12651-12656. doi: 10.1073/pnas.1418794112

Hainmueller, J., Hangartner, D., \& Pietrantuono, G. (2017). Catalyst or Crown: Does Naturalization Promote the Long-Term Social Integration of Immigrants? American Political Science Review, 111(02), 256-276. doi: 10.1017/S0003055416000745

Hammar, T. (1990). Democracy and the nation state: Aliens, denizens, and citizens in a world of international migration. Aldershot, UK: Avebury Press.

Harpaz, Y., \& Mateos, P. (2018). Strategic citizenship: Negotiating membership in the age of dual nantionality. Journal of Ethnic and Migration Studies, 1-15. doi: 10.1080/1369183X.2018.1440482.

Hewstone, M., Kenworthy, J. B., Cairns, E., Tausch, N., Hughes, J., Tam, T., ... Pinder, C. (2008). Stepping stones to reconciliation in Northern Ireland: Intergroup contact, forgiveness and trust. In A. Nadler, T. E. Malloy, \& J. D. Fisher (Eds.), The social psychology of intergroup reconciliation (pp. 199-226). Oxford University Press.

Hildreth, J. A. D., Gino, F., \& Bazerman, M. (2016). Blind loyalty? When group loyalty makes us see evil or engage in it. Organizational Behavior and Human Decision Processes, 132, 1636. doi: 10.1016/j.obhdp.2015.10.001

infratest dimap. (2017, n.d.). Mehr als die Hälfte der Deutschen gegen doppelte Staatsbürgerschaft [More than half of Germans against dual citizenship]. Retrieved from https://www.infratestdimap.de/umfragen-analysen/bundesweit/umfragen/aktuell/mehr-als-die-haelfte-derdeutschen-gegen-doppelte-staatsbuergerschaft

Kang, S. K., \& Bodenhausen, G. V. (2015). Multiple identities in social perception and interaction: Challenges and opportunities. Annual Review of Psychology, 66, 547-574. doi: 10.1146/annurev-psych-010814-015025 


\section{PERCEIVED CITIZENSHIP AND GROUP LOYALTY}

Kunst, J. R., Thomsen, L., \& Dovidio, J. F. (2018a). Divided loyalties: Perceptions of disloyalty underpin bias toward dually-identified minority-group members. Journal of Personality and Social Psychology. doi: 10.1037/pspi0000168

Kunst, J. R., Dovidio, J. F., \& Dotsch, R. (2018b). White look-alikes: Mainstream culture adoption makes immigrants "look" phenotypically White. Personality and Social Psychology Bulletin, 44, 265-282. doi: 10.1177/0146167217739279

Levy, A., Saguy, T., Halperin, E., \& van Zomeren, M. (2017a). Bridges or Barriers? Conceptualization of the Role of Multiple Identity Gateway Groups in Intergroup Relations. Frontiers in Psychology, 8, 1097. doi: 10.3389/fpsyg.2017.01097

Levy, A., Saguy, T., van Zomeren, M., \& Halperin, E. (2017b). Ingroups, outgroups, and the gateway groups between: The potential of dual identities to improve intergroup relations. Journal of Experimental Social Psychology, 70, 260-271. doi: 10.1016/j.jesp.2016.09.011

Levy, A., van Zomeren, M., Saguy, T., \& Halperin, E. (2017c). Intergroup emotions and gateway groups: Introducing multiple social identities into the study of emotions in conflict. Social and Personality Psychology Compass, 11(6), e12320. doi: 10.1111/spc3.12320

Love, A., \& Levy, A. (2019). Bridging group divides: A theoretical overview of the "what" and "how" of gateway groups. Journal of Social Issues. doi: 10.1111/josi.12327

Marcus-Newhall, A., Miller, N., Holtz, R., \& Brewer, M. B. (1993). Cross-cutting category membership with role assignment: A means of reducing intergroup bias. British Journal of Social Psychology, 32(2), 125-146. doi: 10.1111/j.2044-8309.1993.tb00991.x

Mepham, K., \& Verkuyten, M. (2017). Citizenship representations, group indispensability and attitudes towards immigrants' rights. International Journal of Intercultural Relations, 61, 54-62. doi: 10.1016/j.ijintrel.2017.09.004 


\section{PERCEIVED CITIZENSHIP AND GROUP LOYALTY}

Mummendey, A., Klink, A., \& Brown, R. (2001). Nationalism and patriotism: National identification and out-group rejection. British Journal of Social Psychology, 40(2), 159-172. doi: 10.1348/014466601164740

Muthén, L.K., \& Muthén, B.O. (1998-2012). Mplus users guide. 7th edition. Los Angeles, CA: Muthén \& Muthén.

Pauker, K., \& Ambady, N. (2009). Multiracial faces: how categorization affects memory at the boundaries of race. Journal of Social Issues, 65, 69-86.

Pogonyi, S. (2018). The passport as means of identity management: Making and unmaking ethnic boundaries through citizenship. Journal of Ethnic and Migration Studies, 1-19. doi: 10.1080/1369183X.2018.1440493.

Preacher, K. J., \& Hayes, A. F. (2008). Asymptotic and resampling strategies for assessing and comparing indirect effects in multiple mediator models. Behavior Research Methods, 40(3), 879-891. doi: 10.3758/BRM.40.3.879

Raijman, R., Davidov, E., Schmidt, P., \& Hochman, O. (2008). What does a nation owe noncitizens? National attachments, perception of threat and attitudes towards granting citizenship rights in a comparative perspective. International Journal of Comparative Sociology, 49(2-3), 195-220. doi: 10.1177/0020715208088912

Riek, B. M., Mania, E. W., \& Gaertner, S. L. (2006). Intergroup threat and outgroup attitudes: A meta-analytic review. Personality and Social Psychology Review, 10(4), 336-353. doi: $10.1207 / \mathrm{s} 15327957$ pspr1004_4

Ronkainen, J. K. (2011). Mononationals, hyphenationals, and shadow-nationals: multiple citizenship as practice. Citizenship Studies, 15(2), 247-263. doi: $10.1080 / 13621025.2011 .549723$

Shadid, W. A. (2006). Public debates about Islam and the awareness of Muslim identity in the Netherlands. European Education, 38, 10-22. doi: 10.2753/EUE1056-4934380201. 


\section{PERCEIVED CITIZENSHIP AND GROUP LOYALTY}

Silver, M. D. (1997). Group loyalty and group identification: the initial development and evaluation of a new measure of group loyalty (Doctoral dissertation, The Ohio State University). Retrieved from https://etd.ohiolink.edu/rws_etd/document/get/osu1202773243/inline

Sniderman, P., \& Hagendoorn, L. (2007). When ways of live collide: Multiculturalism and its discontent in the Netherlands. Princeton: Princeton University Press.

Stevenson, C., Dixon, J., Hopkins, N., \& Luyt, R. (2015). The social psychology of citizenship, participation and social exclusion: Introduction to the special thematic section. Journal of Social and Political Psychology, 3, 1-19. doi: 10.5964/jspp.v3i2.579.

Verkuyten, M. (2009). Support for Multiculturalism and Minority Rights: The Role of National Identification and Out-group Threat. Social Justice Research, 22(1), 31-52. doi: $10.1007 / \mathrm{s} 11211-008-0087-7$

Verkuyten, M. (2018). The benefits of studying immigration for social psychology: Immigration and social psychology. European Journal of Social Psychology, 48(3), 225-239. doi: 10.1002/ejsp.2354

Verkuyten, M. (2009). Support for multiculturalism and minority rights: The role of national identification and out-group threat. Social Justice Research, 22(1), 31-52. doi: $10.1007 / \mathrm{s} 11211-008-0087-7$

Verkuyten, M., Martinovic, B., \& Smeekes, A. (2014). The multicultural jigsaw puzzle: Category indispensability and acceptance of immigrants' cultural rights. Personality and Social Psychology Bulletin, 40(11), 1480-1493. doi: 10.1177/0146167214549324

Wimmer, A., \& Glick Schiller, N. (2002). Methodological nationalism and beyond: nation-state building, migration and the social sciences. Global Networks, 2(4), 301-334. doi: $10.1111 / 1471-0374.00043$ 


\section{PERCEIVED CITIZENSHIP AND GROUP LOYALTY}

Yle News. (2017, February 3). Survey: Half of Finns see Finnish-Russian dual citizens in the Defence Force as a serious threat. Retrieved from https://yle.fi/uutiset/osasto/news/survey half of finns see finnishrussian dual citizens in the defence force as a serious threat/9441898

Zdaniuk, B., \& Levine, J. M. (2001). Group Loyalty: Impact of Members' Identification and Contributions. Journal of Experimental Social Psychology, 37(6), 502-509. doi: 10.1006/jesp.2000.1474. 


\section{PERCEIVED CITIZENSHIP AND GROUP LOYALTY}

Appendix 1. An example of a LinkedIn profile used in the study (dual citizenship condition in Finland).

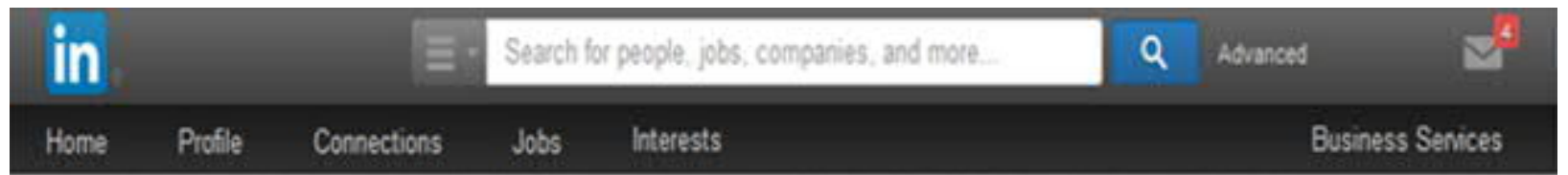

Are You A Prolessor? - Apply Now To The Exclusive Bristol Who's Who of European Prolessionals | Read More z

\section{Sergey Sidorov}

Age 30 years old

Birthplace Russia

Current residence. Finland, Espoo, since 2005

Current occupation. unemployed

Education: CIS, Computer Information Systems

Interests. Russian culture, politics, international affairs

Citizenship, Finnish + and Russian

Send Sergey Intlail

\& $\mathbf{H}$ Contactinto
Onko työkykyjol apua yritystoimi

Katso videot *

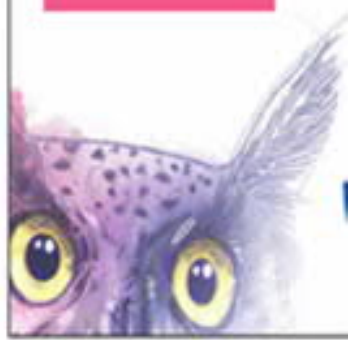

People Also Viewed

Note: Due to copyright issues, the original photo is replaced with a blank profile picture. 